\title{
Competitiveness of Groundnut Processing in Adamawa State, Nigeria
}

Kwaji Emmanuel ${ }^{1 *}$ Dr. Obayelu Abiodun Elijah ${ }^{2}$ Prof. Rahman Akintayo Sanusi ${ }^{2}$ Prof. Shittu Taofik Akinyemi ${ }^{3}$ 1.M. AgSE student from Department of Agricultural Economics and Environmental Policy programme, Centre of Excellence in Agricultural Development and Sustainable Environment (CEADESE), Federal University of Agriculture (FUNAAB), Abeokuta, Nigeria. P.M.B 2240, Alabata Road, Abeokuta, Ogun State

2.Department of Agricultural Economics and Farm Management, Federal University of Agriculture, Abeokuta (FUNAAB), Ogun State, Nigeria

3.Department of Food Science and Technology (FST), Federal University of Agriculture (FUNAAB), Abeokuta, Nigeria

The research is financed by Kwaji Emmanuel, Student of Agricultural Economics and Environmental Policy programme (M.AgSE), Centre of Excellence in Agricultural Development and Sustainable Environment. Federal University of Agriculture (FUNAAB), Abeokuta, Nigeria.

\section{Abstract}

The study assessed the competitiveness of groundnut processing in Adamawa State, Nigeria. The objective was to examine the competitiveness of groundnut processing in the study area. Secondary and primary data were used; structured questionnaire was used to collect primary data from 200 groundnut processors using multistage sampling procedure from 10 selected Local Government Area. The data were analyzed using policy analysis matrix (PAM). The analysis revealed that the processors private profit was ( $\$ 5,153,672.4 / \mathrm{MT})$, social profitability (-6,112,076.31/MT). Results of sensitivity analysis revealed that groundnut processing is competitive in Adamawa State and DRC ratio still remain negative indicating that the processing of groundnut does not have comparative advantage at social price. The study recommends that; Policy makers should discourage any policy measures to import groundnut or groundnut products and encourage the domestic production that will boost output to ensure availability of raw groundnut throughout the year for groundnut processors.

Keywords: competitiveness, groundnut, processing, matrix, policy

DOI: $10.7176 / \mathrm{JBAH} / 11-24-03$

Publication date: December $31^{\text {st }} 2021$

\section{Introduction}

Groundnut (Arachis hypogea L.) is refers to as 'Gyadda in Hausas", to the Ibos as 'Opapa', the Yorubas as 'Epa,' the Americans as peanuts, and the French as arachides (Hogendorn, 1978). It is also known as monkey nut, gobber pea and belongs to the family leguminosea. It originated from Latin America, and Portuguese introduce it into West Africa from Brazil in the $16^{\text {th }}$ Century (Hamidu, et.al., 2006). It is an important cash crop, annual legume and it is one of the world's principal oil seed crops, which is now widely cultivated throughout the tropical, sub-tropical, warm temperate areas and is grown on about 23.95 million ha worldwide with the total production of 36.45 million tones and an average yield of $1520 \mathrm{~kg} / \mathrm{ha}$ in developing countries (Aigco, 2019)

It was revealed that Nigeria is the largest groundnut producer in West Africa, accounting for $51 \%$ of production in the region and contributes $10 \%$ of total global production and $39 \%$ that of Africa (Ajeigbe, et..al., 2015). Nigeria is the largest groundnut producer in Africa accounting for $30 \%$ of the total Africa's nut production. The nuts are mainly grown in the dry areas of Nigeria including Kano, Kwara, Sokoto, Zamfara, and Kaduna (Ellen, et al., 2017). It was noted that between 1956 and 1967, groundnut was the country's most important sole export crop, exemplified by the famous Kano groundnut pyramids. Groundnuts account for $70 \%$ of the total export earnings for the country (Girei et.al., 2017). Nigeria mainly exports its nuts to Indonesia and European Union (Ellen, et al., 2017). Groundnut serves as the major source of livelihoods for small-scale farmers in Northern Nigeria and edible oil. Being a labour-intensive crop, it generates employment for the rural poor; it is planted on about $34 \%$ of total cultivated area and contributes $23 \%$ of household cash revenue (Ajeigbe, et..al., 2015).

Groundnut is the main export crop of Nigerian Northern states and bulk of the crop is produced at the latitude $11^{0} \mathrm{~N}$. Groundnut is the $13^{\text {th }}$ worldwide most essential food crop, and $4^{\text {th }}$ important oil seed-crop (Smith, $2002)$. Groundnut kernels is a rich source of edible oil (43-55\%), carbohydrates $(10-20 \%)$ and protein $(25-28 \%)$ (Cockburn et.al., 1998). About two thirds of global production is crushed for oil and the remaining one third is consumed as food. Its cake is used as feed for livestock or for making other food products for human consumption and haulms provide quality fodder for feeding livestock (Cockburn et.al., 1998). Groundnut seeds are nutritional source of vitamin E, zinc, iron, calcium, phosphorus riboflavin, thiamine niacin, falacin, magnesium, and potassium (FAO, 2011). 
Groundnut is one of the most popular commercial crops. Nigeria produced 3,028,571metric tons of peanuts which make it the third largest groundnut producing country in the world. He also reported that groundnut is cultivated in many countries and leading producing countries are China, India, Nigeria, United State, and Sudan etc (FAO, 2012)

The nuts are consumed roasted, boiled or as confectionary, peanut butter, snack nuts and also crushed to produce oil, etc. which is mostly used for cooking (Nigam, et.al., 2006). It is also used for other industrial purposes such as; pharmaceuticals as carrier, cosmetics and for the production of margarine (Nigam, et.al., 2006). The by-product, meal (cake) is used for both livestock and human consumption. The production of Groundnut in Nigeria as in other major producing areas is largely a smallholder crop grown under rainfall conditions in semiarid areas; Although it is grown in commercial farms in America and Europe, the developing countries, with their small scale production, account for over 95 and 94 per cent of world groundnut area and production respectively (Harkness, et.al., 1976). Production is concentrated in Asia and Africa. Asia accounts for 60 and $70 \%$ of world area and product respectively. India $(35 \%$ area $28 \%$ production), China $(17 \%$ area, $34 \%$ production) are the major producers in Asia and Africa accounts for 35\% of the global area. The most common commercial products of groundnut are: groundnut oil, groundnut cake and fried peanuts which are sold at market places or hawked on the street (Hogendorn, 1978).

Processing of agricultural products is generally accepted as the efficient method of enhancing the shelf-life of produce. Such processed products provide local foods for consumption among the rural areas (Zuberu, et.al., 2013). Groundnut oil is widely used in cooking, including frying, basting, confectioneries, peanut butter, manufacture of margarines and shortenings (Aigco, 2019).

Farm products' processing plays a significant role in the economies of developing Countries, which accounts between $51 \%$ and $60 \%$ of value added by manufacturing and $60 \%$ and $70 \%$ of the total industrial development. Over half of the manufacturing activities in the developing countries of the world consist of agroindustries preserving and transforming agricultural raw materials (Olayide and Heady1985). Processing is one of the most important physical functions of agricultural marketing which is an important component of agribusiness development, because a large portion of farm production undergo some degree of change between harvesting and final use (Olayide and Heady1985).

However, agro-processing is capable of strongly shaping farm production decisions. It enables quality enhancement, preservation and differentiation of farm production thereby enhancing its marketability. It has also been noted that Agricultural processing activities are small-scale and require low investment capital, hence can easily be undertaken by women (FAO, 2012). Consequently, the gains of increased agricultural productivity and sustainable agricultural development will not be fully realized if not sustained through the development of a viable processing sector to support the technical progress attained in production, because local processing of groundnut to produce cake and oil has not met the domestic demand for vegetable oil (Adam, et.al.,2018)

The processing of groundnut is both the source of income and employment to a large proportion of rural women in northern Nigeria, there by facilitate, the achievement of the Millennium Development Goal number three (promotion of gender equality and women empowerment) in northern Nigeria (Aboki, 2015) .In general groundnut has contributed immensely to the development of the Nigerian economy and employment generation particularly among the rural groundnut processors and expands the production (FAO, 2019)

An increased urbanization, distance between home and work-place (FAO, 2011) Working women and changes in family cohesion has increased demand for shelf-stable, convenience and value added food (FAO, 2019). In Nigeria, the processing of groundnut into various products is mostly done by women either for home consumption or for commercial purposes (Ihekoronye and Ngoddy, 1985).

Many studies have been conducted on different aspects and nodes of the groundnut, despite the importance of groundnut oil and cake processing ventures in employment generation and poverty reduction among the rural population in northern Nigeria (Samuel and Ocholi. 2017). The productivity of groundnut in Nigeria have not grown sufficiently due to under investment in existing processing technologies, slow adoption to new improved technology, as constraints associated with lagging infrastructure. The gains of increased agricultural productivity will not be fully realized if not sustained through the development of a viable processing (Ana, et.al., 2010). The objectives of the research were to assess the competitiveness of groundnut processing and the constraints faced by the processors in Adamawa State, Nigeria. In the 1970s, global trade in oil and meal exceeded trade in whole nuts, while in 1980s the shifts in relative transport costs in favour of shipping whole nuts and use of groundnuts for food rather than oilseeds has led to decrease in global trade for groundnut products (cake and oil) and considerable increases in the export of whole nuts (Porter and Kramer, 2007).

Developing competitive agro-industries is crucial for generating employment and income opportunities that will improve the quality of, and the demand for farm products, which have the potential to provide employment for the rural population not only in farming, but also in off-farm activities such as processing, handling, packaging, transporting and marketing of food and agricultural products World (Bank, 2008).

Therefore, it is crucial to maintain the competitiveness of groundnut processing Competitiveness which 
refers to the set of institutions, factors and policies that determine the level of productivity of a given country (Johnny, et.al., 2014), that is equivalent to strong performance of economies relative to other countries and strong performance which means economic growth, success in exports and increased wellbeing (Boland, 2009) Competitiveness is the fundamental determinant of the level of prosperity a country can sustained.

\section{Materials and methods}

\subsection{Sampling and data collection}

The target population for this study was the groundnut processors. A multistage sampling technique was used for this study.The first stage was the purposive selection of ten (10) local Government areas (Hong, Michika, Gombi, Maiha, Mubi North and Mubi south, Girei, Jemita, Yola North, and Ganye) from the 16 Local Governments Areas known for the production of groundnut in the state. The second stage was the purposive selection of four (4) major groundnut processing communities in each of the selected Local Government Areas, adding up to 40 communities. The third stage involves random selection of five (5) groundnut processors in each of the 40 selected communities making a total of 200 groundnut processors for the study). Primary data was collected using structured questionnaire, while secondary information was obtained from published and unpublished materials, textbooks, thesis and journals to complement the primary data

\subsection{Analytical framework}

The policy analysis matrix (PAM) frame work was used to assess the competitiveness of groundnut processing estimated using enterprise budgets at market prices to measure the commercial profitability /competitiveness of various activities in the system, and by using social opportunity costs (comparable world market prices) of the same activities to measure their contribution to the economy as a whole (comparative advantage), taking account of resource transfers and losses due to government policies (Monke, and Pearson,1989)

The first row of the PAM contains the calculation of private profitability; the second row defines social profitability, representing comparative advantage. Social prices (measured at the international market level) reflect valuation of domestic factors. The third row of the PAM represents transfers; vertical divergences which explained the effects of distorting policy or the existence of market failures.

Table 1. The policy analysis matrix framework.

\begin{tabular}{lllll}
\hline & Revenues & Cost & & \\
& & Tradable inputs & Domestic factors & Profits \\
Private prices & A & B & C & D \\
Social prices & E & F & G & H \\
Divergences & I & J & K & L \\
\hline
\end{tabular}

Source: Monke and Pearson, 1989; Masters and Winter-Nelson 1995.

$\mathrm{D}=\mathrm{A}-\mathrm{B}-\mathrm{C}$; Represent Private (actual market) profits (

$\mathrm{H}=\mathrm{E}-\mathrm{F}-\mathrm{G}$; Represent Social profits (N)

$\mathrm{I}=\mathrm{A}-\mathrm{E} ;$ Represent Output transfer divergences

$\mathrm{J}=\mathrm{B}-\mathrm{F}$; Represent Input (tradable) transfer/divergences

$\mathrm{K}=\mathrm{C}-\mathrm{G}$; Represent Factor (non tradable) transfer/ divergences

$\mathrm{L}=\mathrm{D}-\mathrm{H}$; Represent Net policy transfer/divergences.

Where, $\mathrm{A}=P_{a} Q_{g}$; this measures revenues in private (actual market) price (N)

$\mathrm{B}=P_{b} Q_{t}$; this represent tradable inputs cost in private (actual market) price (N)

$\mathrm{C}=P_{c} Q_{n}$; this represent domestic factor cost (actual market) price (

$\mathrm{E}=P_{d} Q_{g}$; this measures revenues in social (efficient) price (N)

$\mathrm{F}=P_{e} Q_{t} ;$ this represent tradable inputs cost in social (N)

$\mathrm{G}=P_{f} Q_{n}$; this represent factor cost in social price (N)

$P_{a}=$ Average market price of groundnut products received by processors (private price of the output, g); (A)

$Q_{g}=$ average quantity of cake and oil ( $\mathrm{Kg}$ and $\mathrm{ltr}$ )

$P_{b}=$ Average domestic price paid by processors for tradable inputs (private price of tradable inputs, t); salt $\mathrm{N}$; peppers $\mathrm{N}$; spices (

$Q_{t}=$ Average quantity of tradable input, (salt $(\mathrm{Kg})$; peppers $(\mathrm{Kg})$; spices $(\mathrm{Kg})$

$P_{c}=$ Average market price of non tradable input paid by processors (private price of non tradable input n);(hired labour:

$Q_{n}=$ Average guantity of non tradable input, n. Total labour (number of labour employed)

$P_{d}=$ International price of groundnut products (N equivalent); (social price of output)

$P_{e}=$ International price of tradable input (social price of tradable input, $\left.\mathrm{t}\right) ;(\operatorname{salt}(\mathrm{N}) ; \operatorname{peppers}(\mathrm{N})$

$P_{f}=$ comparable price for non-tradable (social price of non-tradable input, $\mathrm{n}$ ).

The following indicators of policy analysis matrix was calculated to determine the competitiveness, 
comparative advantage, protection and policy impacts on groundnut processing in the study area.

Nominal protection coefficient on tradable outputs $\mathrm{NPCO}=\mathrm{A} / \mathrm{E}$

Nominal protection coefficient on tradable inputs $\mathrm{NPCI}=\mathrm{B} / \mathrm{F}$

Effective protection coefficient of products $\mathrm{EPC}=(\mathrm{A}-\mathrm{B}) /(\mathrm{E}-\mathrm{F})$

Private cost ratio $\mathrm{PCR}=\mathrm{C} /(\mathrm{A}-\mathrm{B})$

Domestic resource costs $\mathrm{DRC}=\mathrm{G} /(\mathrm{E}-\mathrm{F})$

Social cost-benefit ratio $\mathrm{SCB}=\mathrm{F}+\mathrm{G}) / \mathrm{E}$

\subsubsection{Nature of Data and Modelling Assumptions for Policy Analysis Matrix (PAM)}

The Policy Analysis matrix Modelling was used to assess the competitiveness of Groundnut processing in the study area, under existing technologies and prices. The PAM approach requires the formation of accounting matrices for revenues, costs, and profits (revenues minus costs). Costs are defined in two columns as tradable inputs and domestic factors.

However, in this study, PAM was computed for processors. The data used was the average of data obtains from ten (10) selected Local Government in Adamawa state, the most difficult task was the estimation of social prices for outputs and inputs which can be cumbersome to estimate social prices and decompose inputs into their tradable and non-tradable components (Yao and Genio, 1993). However, decomposing all input costs is a tedious task and has very insignificant effect on results (Monke and Pearson, 1989). World reference prices July, 2019 were used in estimating the social prices for both inputs and output. The social price for domestic factors of processing was estimated by application of the social opportunity cost principle. Since these factors are not tradable opportunity costs was estimated through observations of rural factor markets in the study area.

The prevailing wage rate was used for the estimation of private cost of labour in the case of hired labour. While in the case of family labour, the general principle was to value family labour at its opportunity cost Gittinger, 1982). The social price of labour for this study was in line with the approach used by Yao, 1997. who divide labour into peak-season and off-season components. The rate in the peak-season is the opportunity cost of labour for the period considered and the opportunity of labour off peak season is half the prevailing wage rate. This was calculated as follows:

$$
S P_{L}=\frac{W_{p}+0.5 W_{0}}{2}
$$

$S P_{L}=$ social price of labour ( $) ; W_{p}=$ prevailing wage rate in peak season $(\mathrm{N}) ; w_{o}=$ prevailing wage rate in off peak season.(

\subsection{Measures of competitiveness}

\subsubsection{Private Profitability (PP)}

The term private refers to observed revenues and costs reflecting actual market prices received or paid by farmers, merchants, or processors in the agricultural system. Private profits, D, are the difference between revenues $(A)$ and costs $(B+C)$; and all four entries in the top row are measured in observed prices. If private profits are negative $(\mathrm{D}<0)$, operators are earning a subnormal rate of return and thus can be expected to exit from this activity unless something changes to increase profits to at least a normal level $(\mathrm{D}=0)$. Alternatively, positive private profits $(\mathrm{D}>0)$ are an indication of supernormal returns and should lead to future expansion of the system (Mamza, 2014).The private profitability will be calculated as:

$\mathrm{PP}=P_{a} Q_{g}-\left(P_{b} Q_{t}+P_{c} Q_{n}\right)$

\subsubsection{Domestic Resource Cost Ratio (DRC)}

The domestic resource cost ratio (DRC), defined as the factor cost in social prices (G) by the value added in social price $(\mathrm{E}-\mathrm{F})$, it will serves as a proxy measure for social profits. It compares the opportunity cost of using domestic resources (land, labour, and capital) and non tradable input to the value added in social (World) prices (Scandizzo and Colin, 1980). A DRC less than one (DRC $<1)$ indicates a value-adding activity which has some comparative advantage relative to world-market competitors. A DRC greater than one (DRC $>1)$ indicates that the activity is value-subtracting, as the opportunity cost of resources used exceeds the value of what is gained. Domestic resource cost ratio was expressed as: $(D R C)=\mathrm{G} /(\mathrm{E}-\mathrm{F})$

$\mathrm{DRC}=\frac{P_{f} Q_{n}}{P_{d} Q_{q}-P_{e} Q_{t}}$

\subsubsection{Private Cost Ratio}

Private cost ratio (PCR) measures the competiveness of a commodity system at the farm level. It explain the ratio of domestic factor costs $(\mathrm{C})$ to value added in private prices $(\mathrm{A}-\mathrm{B})$; that is, $\mathrm{PCR}=\mathrm{C} /(\mathrm{A}-\mathrm{B})$. If $\mathrm{PCR}$ is less than one $(\mathrm{PCR}<1)$ it indicate that the system is competitive in the processing of groundnut, while the PCR greater than one $(\mathrm{PCR}>1)$ reveal that the system is not competitive in the processing of groundnut. It also serves as a proxy measure for private profits when comparing between two systems for competitiveness (Mamza, 
2014).This will be calculated as:

$$
\mathrm{PCR}=\frac{P_{c} Q_{n}}{P_{a} Q_{g}-P_{b} Q_{t}}
$$

\subsection{Measures of comparative advantage}

\subsubsection{Social Profitability}

Social profits measure efficiency or comparative advantage. For a comparison of identical outputs, results can be taken directly from the second row of the PAM matrix-social profits equal social revenues less social costs, $\mathrm{H}=$ (E - F - G). When social profits are negative, a system cannot survive without assistance from the government. Such systems waste scarce resources by producing at social costs that exceed the costs of importing. The choice is clear for efficiency-minded economic planners: enact new policies or remove existing ones to provide private incentives for systems that generate social profits, subject to non efficiency objectives (Adeoye, and Oni, 2013).

$\mathrm{SP}=P_{d} Q_{g}-P_{e} Q_{t}-P_{f} Q_{n}$

\subsubsection{Social Cost Benefit Ratio}

The social cost benefit (SCB) is defined as the ratio of total resources cost $(F+G)$ to the revenue E. A SCB ratio less than one $(\mathrm{SCB}<1)$ indicates a value-adding activity which has some comparative advantage relative to world-market competitors. An SCB greater than one ( $\mathrm{SCB}>1)$ indicates that the activity is value-subtracting, as the opportunity cost of resources used exceeds the value of what is gained. Within each category, activities ranked by SCB contribute more value addition (or less value subtraction) per unit of resources used.

$\mathrm{SCB}=\frac{P_{b} Q_{t}+P_{f} Q_{n}}{P_{d} Q_{q}}$

\subsection{Indcators of protection}

\subsubsection{The Nominal Protection Coefficient (NPCI)}

The Nominal Protection Coefficient (NPCI) is the ratio that contrasts the observed (private) commodity price with a comparable world (social) price. This ratio indicates the impact of policy (and of any market failures not corrected by efficient policy) that causes a divergence between the two prices. The NPC on tradable outputs (NPCO), defined as A/E, indicates the degree of output transfer;

An NPC $>1$ reveals that processors are protected for the product. Similarly using input costs, the nominal protection coefficient of tradable inputs (NPI), measures the ratio of the private cost of tradable inputs to their social cost (Ajeigbe, et.al., 2015)

When NPI $<1$, Processors experience protection or subsidization for input purchase prices.

$$
\mathrm{NPCO} \text { or NPCI }=\frac{P_{a} Q_{g}}{P_{d} Q_{g}}
$$

\subsubsection{The Effective Protection Coefficient (EPC)}

The effective protection coefficient (EPC) is a measure of the net effect of distortions or negative protection on outputs and tradable inputs. The effective protection coefficient (EPC), is the ratio of value added in private prices $(A-B)$ to value added in world prices $(E-F)$, or $E P C=(A-B) /(E-F)$. This coefficient measures the degree of policy transfer from product market-output and tradable-input-policies. For an EPC $>1$, processors are protected for the value-added produced (Adeoye, and Oni, 2013).

$$
\mathrm{EPC}=\frac{P_{a} Q_{g}-P_{b} Q_{t}}{P_{d} Q_{g}-P_{e} Q_{t}}
$$

\subsubsection{Profitability Coefficient (PC)}

Profitability coefficient (PC) is an extension of the EPC to include factor transfers, it is defined as the ratio of private and social profits or $\mathrm{PC}=(\mathrm{A}-\mathrm{B}-\mathrm{C}) /(\mathrm{E}-\mathrm{F}-\mathrm{G})$, or $\mathrm{D} / \mathrm{H}$. The $\mathrm{PC}$ measures the incentive effects of all policies and thus serves as a proxy for the net policy transfer, since $\mathrm{L}=(\mathrm{D}-\mathrm{H})$. Its usefulness is restricted when private or social profits are negative, since the signs of both entries must be known to allow clear interpretation (Adeoye, and Oni, 2013).

$$
\mathrm{PC}=\frac{P_{a} Q_{g}-P_{b} Q_{t}-P_{c} Q_{n}}{P_{d} Q_{g}-P_{e} Q_{t}-P_{f} Q_{n}}
$$

\subsection{Sensitivity Analysis}

Policy Analysis Matrix has often been criticized due to the static nature of it analysis, However, to minimize this issue, sensitivity analysis was employed to examine the impact of changes in parameters of the private profitability and social profitability (Monke, E. A. and Pearson, 1989). Sensitivity analysis is important, because the parameters (tradable inputs, non tradable inputs, revenue and foreign exchange) used in constructing a given 
enterprise budgets such as inputs are usually mean values calculated from a range of observed values, because the prices used in calculating social profitability are often estimated prices or projected prices (Ogbe and Affiku, 2011). For this study, the processors revenue and inputs were varied ( $\pm 5, \pm 10, \pm 15$ and $\pm 20 \%$ increase and decrease respectively) following (Ogbe and Affiku, 2011 and Ajeigbe, et.al., 2015).

\section{Result and Discussion}

\subsection{Policy Analysis Matrix of Groundnut Processing}

\subsubsection{Private profitability}

The Private profitability was obtained from the first raw from groundnut processing in the study area is competitive given current price of inputs, output and technologies which indicates that groundnut processors obtained their groundnut they used for processing at affordable prices and therefore, they are earning higher returns, this is in lined with (Ademola, et.al., 2017) that they are earning supernormal returns and should lead to future expansion of the system.

The results in table 3 , It was found that private profitability was positive (N5,153,672), which is the actual profit that was received by the groundnut processors, this means that

\subsubsection{Social profitability}

In the second raw of table 3 , the social profit was $(\mathrm{N}-6,112,076.31)$ this means that under the comparable international world price the system was not profitable and does not have comparative advantage. the negative social profit means that groundnut processing cannot survive the high cost of importing raw groundnut or groundnut products without the assistance from the Government, this means that to import groundnut is to waste scarce resources by importing at social cost that exceed the domestic cost of producing it. This is a clear indication for economic planners to provide private incentives to encourage domestic producers rather than importing (Adeoye, and Oni, 2013)

\subsubsection{Net Transfer}

The net transfer or divergence shows that, since the net profit transfer is negative $(-958,403.91)$, it means that, the net effect of the policies was to tax the groundnut processors, because it does not require any protection or subsidy to yield substantial profit. The transfers on revenue were negative showing that groundnut processing using current technology was being taxed probably through the low selling prices of groundnuts products. However, for the resource costs, the tradable input transfer $(-8,356,201.7)$ was negative which indicating that the processors were paying lower prices for the inputs used in processing, which means that there is no need for incentives for the processing activities, since It was found that revenue at market prices (local) is higher than revenues at economic prices (global).

Table 2. Policy Analysis matrix for Groundnut processors $(\mathrm{N} / \mathrm{t})$.

\begin{tabular}{lllll}
\hline & Revenues & \multicolumn{2}{c}{ Cost } & \\
Private prices & $\mathrm{A}=12,066,680$ & $\mathrm{~B}=6,322,350$ & $\mathrm{C}=590,657.60$ & $\mathrm{D}=5,153,672.4$ \\
Social prices & $\mathrm{E}=8,684,965$ & $\mathrm{~F}=14,678,551.7$ & $\mathrm{G}=118,490$ & $\mathrm{H}=-6,112,076.31$ \\
Divergences & $\mathrm{I}=3,381,714.51$ & $\mathrm{~J}=-8,356,201.7$ & $\mathrm{~K}=472,167.5$ & $\mathrm{~L}=-958,403.91$ \\
\hline
\end{tabular}

Source: Field survey, 2019

\subsubsection{Indicators for Protections}

From Table 4, the NPCO for groundnut processors in the study area is lower than one indicating that domestic prices in Adamawa, are below their corresponding international world reference prices. Similarly, NPCI values of less than one in both cases suggest that the government policies are reducing input costs for groundnuts processors since they are not taxed. NPC values less than one for input and output markets which mean that the processors inputs have lower cost which make their processing activities cheap and easier without support from Government.

The EPC which is known as reliable indicator of the effective incentives than the NPC, as the full impact of a set of policies includes both output price enhancing (import tariffs) and cost reducing (input subsidies) effects. The EPC nets out the impact of protection on inputs and outputs, and reveals the degree of protection accorded to the value added process in the processing activities. The EPC value less than one indicate that value added at market prices in Adamawa state was less than value added at the world reference prices.

\subsubsection{Profitability Coefficient, PCR}

The profitability coefficient (PC), is a measure of the degree to which net transfers have caused private profits to exceed social profits, it provides an indication of the total incentive effect which make it more complete measure than EPC from table this shows how much the system can afford to pay domestic factors and still remain competitive (break-even) the PCR was 0.1028 . Since the private cost ratio are less than one (PCR $<1$ ), it indicate that the system is competitive in the processing of groundnut which enabled their value added to the system to earn excess profit. It also serves as proxy measure for private profit when comparing between two systems for competitiveness (Adeoye, and Oni, 2013) 
The (DRC and SCB) used in this thesis for groundnuts processors as reported in Table 4, indicate the conclusions reached with the protection coefficients. DRC values for groundnuts processors which is lower than one (-0.0198) is value-adding activity which has some comparative advantage relative to world-market which is a clear indication that groundnuts processing has a comparative advantage in the study area, since it is profitable in the study area with actual market prices. This means that it is not socially desirable for the country to import groundnut or groundnut products.

The SCB values greater than one (1.7038) indicate value-subtracting activities, because the opportunity cost of resources used in social price is more than the value gained, this means that without government support the system cannot survive importing of groundnut or groundnut products since there is low outcome in relation to resource used in world market.

In other words groundnut processing is profitable in Adamawa under private prices. (Ana et.al. 2010)

Table 3: Summary of indicators of protection

\begin{tabular}{|c|c|c|}
\hline Indicators of Competitiveness & Ratios & Interpretation \\
\hline Private profitability ratio, $\mathrm{PCR}=\mathrm{C} /(\mathrm{A}-\mathrm{B})$ & 0.1028 & PCR $<1$,implies competitive \\
\hline Private cost benefit ratio, $\mathrm{PCBR}=(\mathrm{B}+\mathrm{C}) / \mathrm{A}$ & 0.573 & $\operatorname{PCBR}<1$, implies competitive \\
\hline Private profitability, $\mathrm{PP}=(\mathrm{A}-\mathrm{B}-\mathrm{C})$ & $5,153,672.4$ & $\mathrm{PP}>0$, implies competitive \\
\hline \multicolumn{3}{|l|}{ Indicators of Comparative Advantage } \\
\hline Domestic resource cost, $\mathrm{DRC}=\mathrm{G} / \mathrm{E}-\mathrm{F}$ & -0.0198 & $\mathrm{DRC}<0$ no comparative advantage \\
\hline Social cost benefit, $\mathrm{SCB}=\mathrm{F}+\mathrm{G} / \mathrm{E}$ & 1.7038 & SCB $>1$ no comparative advantage \\
\hline Social profit, $\mathrm{SP}=\mathrm{E}-\mathrm{F}-\mathrm{G}$ & $-6,112,076.31$ & $\mathrm{SP}<0$ no comparative advantage \\
\hline \multicolumn{3}{|l|}{ Indicators of Protection } \\
\hline $\begin{array}{l}\text { Nominal protection coefficient on Input, } \mathrm{NPCI}= \\
\mathrm{B} / \mathrm{F}\end{array}$ & 0.4307 & $\mathrm{NPCI}<1$ implies no protection \\
\hline $\begin{array}{l}\text { Nominal protection coefficient on Output, NPCO } \\
=\mathrm{A} / \mathrm{E}\end{array}$ & 1.3894 & $\begin{array}{l}\text { NPCO }>1 \text { protected by cheap input } \\
\text { price }\end{array}$ \\
\hline Effective protection coefficient, $\mathrm{EPC}=\mathrm{A}-\mathrm{B} / \mathrm{E}-\mathrm{F}$ & -0.9584 & $\mathrm{EPC}<1$ implies no protection \\
\hline Profitability coefficient $\mathrm{PC}=\mathrm{D} / \mathrm{H}$ & -0.843 & $\mathrm{PC}<0$ Absence of incentive \\
\hline Processors subsidy equivalent, $\mathrm{PSE}=\mathrm{L} / \mathrm{A}$ & 0.93 & PSE $>0$ Implies subsidy \\
\hline Subsidy ratio to processors, SRP & 1.30 & SRP $>0$ Implies subsidy \\
\hline Net transfer $\mathrm{L}=(\mathrm{I}-\mathrm{J}-\mathrm{K}$ or $\mathrm{D}-\mathrm{H}$ & $11,265,749$ & Net transfer $>0$ implies Subsidy \\
\hline
\end{tabular}

Source: field survey, 2019

\subsection{Sensitivity Analysis}

Since PAM is a static model that cannot capture the potential changes in prices and Productivity, these results are subject to change with market conditions such as change in domestic prices/ international prices or parity prices of tradable inputs which can change the values of PRC, DRC and SCBR. The sensitivity analysis therefore, illustrates how the PCR, DRC and SCBR ratios for groundnut processors react to various parameter changes (tradable inputs, non tradable inputs, revenue and foreign exchange) and how groundnut products (oil and cake) prices can alter the PCR, DRC and SCBR ratios. Based on the results in Table 4 and assuming that is the real situation of these parameters in the study area and the parameter and revenue were varied by $\pm 5, \pm 10, \pm 15$ and $\pm 20 \%$ as shown in table 4 , the result in table 4 shows the changes in the PCR, DRC and SCBR ratios when the processing parameters and exchange rate were varied by the above percentages following study on Competitiveness of Fish Farming in Lagos State (Adeoye, and Oni, 2013).

Table 4: Sensitivity analysis of Groundnut processing

Increase in the parameters Decrease in parameters

\begin{tabular}{llllllllll} 
Indicators & Base & $5 \%$ & $10 \%$ & $15 \%$ & $20 \%$ & $-5 \%$ & $-10 \%$ & $-15 \%$ & $-20 \%$ \\
& scenario & & & & & & & & \\
PCR & 0.1028 & 0.1079 & 0.1131 & 0.1182 & 0.1234 & 0.0977 & 0.0925 & 0.0874 & 0.0822 \\
DRC & -0.0198 & -0.0018 & -0.0178 & -0.0168 & -0.0158 & -0.0208 & -0.0218 & -0.0227 & -0.0237 \\
SCBR & 1.7038 & 1.7890 & 1.8742 & 1.9594 & 2.0445 & 1.6187 & 1.5334 & 1.4482 & 1.3630 \\
\hline
\end{tabular}

Having varied the parameters and revenue to expect an improvement in the scenario of PCR (0.1028), the PCR ratio were still within the interval $\{0-1\}$ this means that the processing of groundnut is still profitable if it is increased by $5 \%, 10 \%, 15 \%, 20 \%$ and decrease by $-5 \%,-10 \%,-15 \%$ and $-20 \%$ which revealed that groundnut processing is competitive in Adamawa state. The PCR interval $\{0-1\}$ after increased parameters and exchange rate by $20 \%$ shows that Albania olive production is profitable to farmers (Ajeigbe et.al., 2015)

While the parameters were increased and decreased the DRC ratio still remain negative without much deviation from the base scenario $(-0.0198)$ which means that the processing of groundnut does not have comparative advantage at social price. This is line with the study carried out by Ana, et.al.,(2010) on olive 
production When changing the production parameters by $-20 \%$, Albania olive production was not profitable to farmers and of course does not have a comparative advantage (Ajeigbe, et.al., 2015)

\section{Conclusion and recommendations}

The results obtained from the research revealed that groundnut processing in the study area is profitable, competitive and maintained comparative advantage at the private price and there is no comparative advantage at the social price because there is negative net transfer, DRC values less than one and SCB ratio greater than one which indicate value subtracting because the input cost exceeds value gained. The PCR value less than one indicate that the input cost are less than value added in private price which revealed that processors have efficiently utilized domestic resources used for processing. Since the system is competitive with the use of indigenous, the findings of the study express the need for government policy intervention to provide modern groundnut processing for the processors to expand their enterprise, thereby facilitate the attainment of the sustainable Development goal number five(Promotion of gender equality and women's empowerment). The analysis of this study justified the need for Policy makers to discourage any policy measures to import groundnut or groundnut products and encourage the domestic production that will boost output to ensure availability of raw groundnut throughout the year for groundnut processors, modernization of groundnut processing as the source of livelihood for the majority of rural women in the northern Nigeria since it is female dominated and will enhance the overall economic development through the income and employment generation in Adamawa State.

\section{References}

Aboki, P. M. (2015). Traditional and Modern Groundnut Processing and Marketing in North Central Nigeria. $\mathrm{PhD}$ thesis Department of Agricultural Economics, Faculty of Agriculture, University of Nigeria, Nsukka Pp 1-4.

Adam, A., Patricia, B., Brian, D., Alison, E., Erik, G., J. E., Luebering, A. M.,, Melissa, P., John, P. R., Michael, R., Kara R., Amy, T., Jeff, W., Adam, Z. and Alicja Z. (2018). Adamawa state, Nigeria (Online). https://www.britannica.com/place/Adamawa-state-Nigeria (acess on September 10, 2018).

Ademola, O. E., Omotesho, O. A. and Olaghere I. L. (2017). Assessment of plantain value chain in Osun State. Conference proceeding of the 18th Annual National conference of the Nigerian Association of Agricultural Economics held at Federal University of Agriculture, Abeokuta, Nigeria pp3-6

Adeoye, I. B. and Oni, O. A. (2013). Policy Analysis and Competitiveness of Plantain Processing in Southwestern Nigeria. Clarion University of Pennsylvania, Clarion, Pennsylvania: Journal of Sustainable Development in Africa Volume 15(7):1520-5509.

Ajeigbe, H. A., Waliyar, F., Echekwu, C. A., Ayuba, K., Motagi, B. N., Eniayeju, D. and Inuwa, A. (2015). A Farmer's Guide to Groundnut Production in Nigeria. Patancheru pp502-324.

Ana, M.K, Ilir K, Catherine, C.H, and Orkida, T. (2010). Assessing the Comparative Advantage of Albanian Olive Oil Production. International Food and Agribusiness Management Review(13) 1: 8-12.

Boland, M.(2009) What is value added Agriculture? Agricultural Marketing Resource Centre.Washington D C (online). www.agmrc.org

Cockburn, J., Siggel, E., Coulibaly, M. and Vezina, S., (1998). Measuring Competitiveness and Its Sources: The Case of Mali's Manufacturing Sector, Equity and Growth through Economic Research 16. EAGER Publication/BHM pp30-34.

Ellen, O. A., Richard, B. M. and Baba, S. (2017). Analysis of the Groundnut Value Chain in Ghana. World Journal of Agricultural Research 5 (3): pp 177-188.

Food and Agriculture Organization of the United Nations, FAO. (2019). Availlable at (Online). https://www.worldatlas.com/articles/top-peanut-groundnut-producing-countries.html

Gittinger, J. P. (1982). Economic analysis of agricultural project (2nd edition.). Baltimore: John Hopkins UniversityPress. (Online). https://www.scirp.org/reference/ReferencesPapers.aspx?ReferenceID=1084040

Girei, A. A., Audu, S. I., Onuk, E. G. and Onyenye, P. O. (2017). Productivity and Profitability of Groundnut Production (Arachis hypogea L.) in Lafia Local Government Area, Nasarawa State, Nigeria pp1-2.

Hamidu, B. M., Kuli, S. G. and Mohammed, S. (2006). Profitability Analysis of groundnut (Arachis hypogea) processing Among Women Enterprenues in Bauchi metropolis. In: Adepoju, S. O. and Okuneyi, P. B. (eds). Technology and Agricultural Development in Nigeria. Proceeding of the 20th Annual National Conference of Farm Management Association of Nigeria held at Forestry Research Institute of Nigeria, Federal College of Forestry Jos, Plateau State pp368-381.

Hogendorn, J. S. (1978). Nigeria Groundnut Export: Origins and Early Development. Zaria: Ahmadu Bello University Press and Oxford University Press 139pp.

Ihekoronye, A. I. and Ngoddy, P. O. (1985). Integrated, food science and technology for the Tropics. Macmillan Publishers Limited London pp364.

Mamza, A. O., Salman, K. K. and Adeoye, I. B. (2014). Competitiveness of Beef Processing in Borno State of 
Nigeria: A Policy Analysis Matrix Approach. Journal of Agriculture and Sustainability 6(2):132-147.

Monke, E. A. and Pearson, S. R. (1989). The Policy Analysis Matrix for Agricultural Development. The role of Agricultural Policy Analysis pp10-12.

Ogbe, A. and Affiku, P. J. (2011). Proximate Study, Mineral and Anti-Nutrient Composition of Moringa Oleifera Leaves Harvested from Lafia, Nigeria: Potential benefits in poultry nutrition and health. Journal of Microbiology, Biotechnology and Food Sciences 1:pp296-308.

Porter, M. and Kramer M. (2007). Strategy \& Society: The Link Between Competitive Advantage and Corporate Social Responsibility. 9 (Online). http://sustainability.psu.edu. /fieldguide/resources/porter-m-kramer-m2007-strategy-society-the-link-between-competitive-advantage-and-corporate-social-responsibility/

Samuel, P. and Ocholi A. (2017). Analysis of Costs And Returns of Groundnut Processing in Taraba State,Nigeria. Department of Agribusiness, University of Agriculture Makurdi. Journal of Research in Business and Management (5) 6 Pp: 18-26.

Scandizzo, P. L. and Colin, B. (1980). Methodologies for Measuring Agricultural Price Intervention Effects, World Bank Staff Working Paper, June, No.394, The World Bank, Washington, D.C., U.S.A.

Yao, S. (1997). Comparative Advantages and Crop Diversification. A Policy Analysis Matrix for Thai Agriculture. Journal of Agricultural Economics 48: pp 211-222.

Zuberu, T. A., Mumni, S. S. and Oladele, A. S. (2013). The Impact of Research Led Agricultural Producivity Growth on Poverty Reduction in Africa, Asia and Latin America. Contributed paper for the 25th conference of the International Association of Agricultural Economists. 